\title{
Formation of carbonate of lime from the neutral malate of lime
}

\section{Dessaignes}

To cite this article: M. Dessaignes (1849) Formation of carbonate of lime from the neutral malate of lime, Philosophical Magazine Series 3, 34:227, 156-157, DOI: 10.1080/14786444908646198

To link to this article: http://dx.doi.org/10.1080/14786444908646198

册 Published online: 30 Apr 2009.

Submit your article to this journal $₫$

Q View related articles $\sqsubset$ 
metallic substance whatever. The hydroehloric acid was prepared expressly for the purpose; nitrie acid ofly was sometimes employed; the filters were made of paper which was andysed and fotind to conttain no copper; and they were waslyed with eoncentrated nitric abid diluted with an equal volume of distilled water. The capstiles, crucibles, glass rods, bottles, funnels and glisses, were washed with aqua regia, with nitric acid, and in some cases with boiling nitric acid.

The blood employed in these experiments weighed $162 \mathrm{grs.}$, 200 grs., 300 grs., 315 gre., 380 gris., 472 grs.; was cautiously evaporated to dryness in a porcelain capsule, and burnt in a porcelain crucible; the ash was treated witle aqua regia or nitric acid; the solution was evaporated to get rid of the greater part of the acid, then treated with water, filtered into a bottle, subjected to the action of hydrosulphuric acid, and allowed to stand at least eighteen hours that the precipitate might subside; the liquid was filtered to separate this: the filter after being washed with water containing a little hydrosulphuric acid, in a small porcelain capsule, treated with a few drops of aqua regia of nitric acid, allowed to stand, or slightly heated till the colour of the precipitate was 80 modified as to possess the colour of sulphur. The filter was washed, the liquid evaporated, and the residue calcined and treated, after cooling, with two clrops of nitric acid ; it had all the properties of a solution of a salt of copper, for ammonia rendered it blue, and the ferrocyanide of potassium gave a reddish-brown precipitate, and lastly it deposited copper on metallic iron.

From the facts above detailed, the author considers that the existence of copper in the blood cannot be questioned; and he is of opinion, as stated in a memoir presented to the Academy in 1848, that vegetables take from the soil part of the copper which they contain; that herbivorous animals receive it from plants, and man from plants and animals which serve him for food.-Journ. de $P h$. et de Ch., Decembre 1848 .

\section{FORMATION OF CARBONATE OF LIME FROM THE NEUTRAL MALATE OF LIME. BY M. DISGAIGNES.}

The researches of $M$. Piria have proved that asparagine may be regarded as the amide of malic acid. When it is impure and dissolved in water, it soon ferments, and is converted into succinate of ammonia. It occurred to M. Dessaignes that if malic acid, or one of its salts, was susceptible of undergoing the same kind of fermentation, the relation discovered by M. Piria would receive from it a more complete demonstration.

Neutral malate of lime, such as obtained by M. 'Liebig's process from the berries of the mountain ash, was exposed to a somewhat deep stratum of water, in a vessel covered merely with paper. This was in the autumn of 1847 ; after three months, the supernatant water was partly filled with a mucilaginous and unquestionably 
organized product; on this and on the sides of the vessel there were formed abundance of fine crystals of hydrated carbanate of lime. The filtered water slightly precipitated acetate of lead. The formation of carbonate of lime and mucilage ceased as the spring advanced and in the summer. M. Dessaignes observed beneath the malate of lime, which diminished insensibly, the formation of a stratum of very fine and compact prismatic crystals. This stratum was raised by some large bubbles of gas which were given out by the malate of lime. This mass of crystals was dissolved in hot water, precipitated by carbonate of soda and filtered. By this there was obtained a slightly coloured solution, which, with the addition of alcohol and ammonia, precipitated nitrate of lead, nitrate of silver, neutral perchloride of iron, and chloride of barium. The liquor was concentrated, treated with a slight excess of hydrochloric acid, and evaporated to dryness, the residue being repeatedly treated with boiling æther. The athereal solution gave by spontaneous evaporation fine crystals of an acid which was volatilized without decomposing, burnt without residue on platina foil, and was in fact succinic acid.

It appeared to be composed of-

$$
\begin{aligned}
& \text { Ćarbon. . . . . . . . . . . . 40.68 } \\
& \text { Hydrogen ........ 5.08 } \\
& \text { Oxygen ......... 54.24 } \\
& 100 \cdot 00
\end{aligned}
$$

At the sitting of the Academy of Sciences on the 2nd inst. Sir David Brewster was elected one of the eight foreign associate members of the National Institute of France, vacant by the death of the celebrated chemist, M. Berzelius.

\section{JOURNEY TO DISCOVER THE SOURCES OF THE NILE.}

In our number for December last* we announced the arrival of Dr. Bialloblotzky at Alexandria. According to letters since received from him by Dr. Beke, he left Suez for Aden on the 22nd of November, by the East India Company's steam-packet " Adjdaha," by which a free passage had been granted him by the Court of Directors ; and at the latter place he was awaiting (Dec. 11) the arrival from Djiddah of a small steam-vessel with pilgrims returning from Mecca to the Persian Gulf, by which he intended to proceed to Makulla, on the south coast of Arabia. He there expected to meet with an Arab vessel to take him to Mombás, on the east coast of Africa, from which place he would commence his journey into the interior.

Dr. Beke informs us that he has just received a letter from Cap. tain Haines, I.N., Political Agent at Aden, dated Dec. 24, informing him that Dr. Bialloblotzky had left that place for Makulla by the steamer "Sir Charles Forbes," Capt. Lichfield, and it was expected that by the end of the month he would be able to sail from Makulla for Mombás. 